\title{
THE INTERPLAY OF MEANING BETWEEN VERBAL AND VISUAL TEXTS IN A JAPANESE CHILDREN'S BOOK
}

\author{
Dewi Puspitasari* \\ Department of Language and Literature, Faculty of Cultural Studies, Universitas Brawijaya \\ Jl. Veteran, Ketawanggede, Malang 65415, Indonesia \\ d_puspitasari@ub.ac.id
}

Received: $27^{\text {th }}$ January 2021/Revised: $08^{\text {th }}$ March 2021/Accepted: $08^{\text {th }}$ March 2021

How to Cite: Puspitasari, D. (2021). The interplay of meaning between verbal and visual texts in a Japanese children's book. Lingua Cultura, 15(1), 1-9. https://doi.org/10.21512/lc.v15i1.6990

\begin{abstract}
The research aimed to interpret the meaning of aspects in the verbal and visual texts to identify whether these two texts created interplay. It was intended to understand the meaning conveyed by the writer and illustrator in a Japanese children's book entitled 'Kuroino' (Little Shadow). The research used the approaches for verbal text analysis by Halliday about Systemic Functional Linguistics (SFL), and visual text analysis by Kress and van Leeuwen about Visual Grammar (VG). The research method was descriptive qualitative by explaining two data types: clauses in the Japanese language and images in the storybook. The data analysis of every aspect in the three metafunctions of language and the three metafunctions of images show the meaning that completes each other. In the analysis of ideational meaning, interpersonal meaning, and textual meaning, the writer narrates the friendship and adventure of 'Kuroino' (the Black) and Watashi (I). Meanwhile, in the analysis of representational meaning, interactive meaning, and compositional meaning, the illustrator describes two characters in a book entitled 'Kuroino' as the focuses in some pictures. Besides, the illustrator describes the background in detail as if he invites the reader to participate in the adventure of these two characters. Although verbal and visual texts describe a story from two different perspectives, in 'Kuroino', these texts collaborate to create a message in the story with synergy and meaning to be easily understood by the readers by maintaining the entertainment aspect in a story narrated.
\end{abstract}

Keywords: text meaning, three metafunctions, verbal text, visual text, Japanese children's book

\section{INTRODUCTION}

Reading plays an essential role in child development. Reading activity is like eating healthy food; it simultaneously brings pleasure and benefits, such as improving cognitive development and language skill (Attiyat, 2019; Maharsi, Ghali, \& Salma, 2019). However, an annual survey conducted by The National Federation University Co-operative Association shows that most of the students in Japan do not read the book for pleasure. From 10.021 samples, 53,1\% of students answer in this way. Moreover, the student's average daily reading time has decreased to 23,6 minutes per day (Steele, Zhang, \& Song, 2018). Nowadays, local governments and schools in Japan promote Morning Reading Program to improve the reading interest since childhood. Based on the Morning Reading Promotion Association survey in June 2019, reading activities increase to $80 \%$ in elementary school and $50 \%$ in junior high school (Kimura, 2019). The morning reading program is expected to form the behavior pattern to favor reading activity since childhood.

Since childhood, reading activity serves to prepare quality generation with broad insight and pleasure from the reading book (Irhandayaningsih, 2019; Tse et al., 2017). Book generally used by the parent to introduce reading activity since childhood is illustrated children's storybook. The illustrated children's storybook plays a fundamental role in life, entertainment, and education for children in several ways (Maximo, 2019; Qiu, 2019). Illustrated storybook is believed to represent a place or country and describe how people live so that readers can understand the local culture from a site (Belcher, 2018; Ratminingsih \& Budasi, 2018). Illustrated storybook defines the physical characteristics, reflects how to behave, and describes role in a story. In other words, an illustrated book can be understood as a book composed of two elements, namely narrative or verbal text and picture or visual text (Hermawan \& Sukyadi, 2017).

Wee, Kura, and Kim (2018) have discovered several social values illustrated in illustrated children's 
storybooks, such as harmony, empathy, faithfulness, and patience in Japanese society. Besides, most of the children's storybooks from 1990 to 2016 for the age of 3-8 years old illustrate and tell about Japanese cultures, such as clothes, food, entertainment, traditional activity, tradition, social behavior that reflect the value and belief of Japanese people, historical events, and political issues. According to Cao and Yin (2016), most of the research about children's literature is categorized into the perspective of genre and context; and the interaction between readers and text. Many kinds of research from the genre and content perspectives have been frequently conducted, but research from a linguistic perspective is still rare and is not yet wholly done. Thus, the research aims to investigate the illustrated storybook with a linguistic resource approach. It is expected that the research can provide a contribution to recommend children's literature from a different perspective for the reader. Application of the linguistic resource uses Systemic Functional Linguistics (SFL) and Visual Grammar (VG) approaches, which serve as a valid tool to know how children's literature can affect children.

Previous research with a similar topic that combined SFL and VG approaches has been done. The differences of previous research are on the research scope and data source used. Sembiante, Baxley, and Cavallaro (2018) have used illustrated children's storybook with a specific theme, namely issues discussed in children's storybook from the diaspora (a work by an immigrant writer in a place). That research also applies the theory about critical literacy. Meanwhile, the studies conducted by Hayakawa (2015); Hermawan and Sukyadi (2017); Koutsikou and Christidou (2019); Moya Guijarro and Pinar Sanz (2008); Qiu (2019); Zohrabi, Dobakhti, and Mohammadpour (2019) have used a themed storybook with different languages focuses, such as the Indonesian language, Greek language, English, and Mandarin language. Meanwhile, research with illustrated children's storybooks in the Japanese language is still limited to date. Previous research using data in the Japanese language is conducted by Inako (2017); Indrowaty et al. (2018); Murray (2020) on the translation and advertisement in the Japanese language.

Since research using data in children's storybooks in the Japanese language is limited, the research investigates a children's storybook entitled Kuroino (Little Shadow) written and illustrated by Tanaka (2019). The research combines two approaches, namely SFL, as stated by Halliday and Matthiessen (2014), and VG by Kress and van Leeuwen (2020). These two leading theories are based on analyzing verbal and visual texts in a book entitled Kuroino. Thus, it can identify the role of verbal and visual texts in the storybook and create a meaningful story. Verbal text analysis uses a theory of SFL about three metafunctions of language, including ideational meaning, interpersonal meaning, and textual meaning (Halliday \& Matthiessen, 2014). Meanwhile, visual text analysis uses VG theory about three metafunctions of the image, including representational meaning, interactive meaning, and compositional meaning (Kress \& van Leeuwen, 2020). Applying these two theories is expected to interpret the meaning of aspects in verbal and visual texts. Thus, a comprehensive understanding of the message conveyed by the writer and illustrator can be obtained.

\section{METHODS}

The research method is descriptive qualitative. The research procedure resulted in descriptive data in the form of written words or speeches from people and observed behavior. It is intended to understand the phenomenon as experienced by the research subject, namely behavior, perception, motivation, action, and holistically by describing in words and language in a specific context by using several scientific methods (Miles, Huberman, \& Saldafia, 2020). The approach is used to investigate verbal and visual elements in the illustrated children's storybook with the description in words.

Data are provided with the listening method that obtained by listening to the use of language with tapping and note-taking techniques (Sudaryanto, 2015). These techniques are applied by reading data sources, namely illustrated children's storybook entitled Kuroino (Little Shadow) by Tanaka (2019). This book is a children's storybook recommended by the Japanese Board on Books for Young People (JBBY) in 2020. JBBY was established in 1978 as a part of The International Board on Books for Young People (IBBY). Missions from IBBY and JBBY create a peaceful future for children around the world through the book (Doi et al., 2020). Kuroino is a book for children older than three years old (preschool children). It has won awards, Winner of the Nami Concours Purple Island Prize and Shogakukan Children's Book Award.

Data analysis is conducted to answer problems in the research; (1) to analyze verbal text (35 clauses) using a theory of three metafunctions of language, namely ideational meaning, interpersonal meaning, and textual meaning by Halliday \& Matthiessen (2014) and thematic progression by Danes in (Kizil \& Kushch, 2019) and Eggins in (Gunawan \& Aziza, 2017; Yunita, 2018); and (2) to analyze visual text using three metafunctions of the image by Kress \& van Leeuwen (2020), including representational meaning, interactive meaning, and compositional meaning. After conducting the analysis, in the discussion section, the researcher sees the relevance of meaning in verbal and visual texts based on the relationship stated by Liu (2019), whether or not it creates a relation with synergy and meaning.

The result of data analysis is presented in the form of verbal and visual texts. The verbal text is written using the hiragana alphabet with alphabetic transcriptions, while visual text in the form of image representation is in a book entitled Kuroino. 
Data are presented using the informal presentation method, using words without formulation or symbol (Sudaryanto, 2015). The result of data analysis is presented in descriptive form with some images in the children's storybook as a part of data analysis.

\section{RESULTS AND DISCUSSIONS}

Data analysis is described in two phases: verbal and visual meaning analysis in illustrated children's storybook entitled Kuroino (Little Shadow). The discussion describes a relation between verbal text and visual text in the book Kuroino, whether they complete each other and easy to understand. The researcher analyzes the clause in verbal text from three perspectives. First, every clause in a book Kuroino is classified based on the clause system. The clause is then deconstructed based on the Mood system, transitivity structure, and theme-rheme structure. After analysis, the researcher interprets the verbal text based on lexico-grammatical choices as stated in the clause. Lexico-grammatical choices are a reflection of meaning in text comprehensively (Ngongo, Dethan, \& Hyna, 2018; Raeisi, Dastjerdi, \& Raeisi, 2019).

Based on clause analysis in a book Kuroino, it can be known that most of the clauses (77\%) belong to the Mood indicative-declarative type. These clauses, which served as proposition-giving, are statements that exchange information, not goods and services. It can be interpreted interpersonally that in a text entitled Kuroino, the writer provides information or tells a story about the friendship between Kuroino (the Black) and Watashi (I). Meanwhile, 23\% of clauses belong to Mood indicative-interrogative type, classified into 9\% in polar, and $14 \%$ in asking the question. The writer interpersonally provides information and involves readers in an adventure experienced by Kuroino and Watashi. An example is a simple question asked by Watashi「はいっていいの? 」Haitte iino? 'Is it true I can go inside there?', readers are indirectly invited to enjoy an adventure together in this story.

Transitivity analysis in a book entitled Kuroino (see Table 1) shows that the most frequently identified process is material (43\%). The writer uses the words, such as「する」suru 'to do', 「行く」iku 'to go', 「 潜って」kugutte iku 'to crawl',「步く」aruku 'to walk', and so on to describe adventure by Kuroino and Watashi when they met. In the existential process $(20 \%)$, the writer uses words「いた」ita 'there is',

「何かしら」nani kashira 'what is there',「ああ、

お父さん」aa otousan 'there is father', and so on. When enjoying the adventure, Kuroino and Watashi invite the readers to participate in their experience by asking questions, such as「ああ、あれは何かし 5 ? Aa, are wa nani kashira? 'What is there?', which asks about the existence of a thing.

Meanwhile, mental process (14\%), relational process $(11 \%)$, and verbal process $(9 \%)$ in Kuroino text are sequential in terms of amount. In the mental process, the writer uses the words「ょく見てみ よう」yoku mite miyou 'to try seeing thoroughly' and「聞こえた」kikoeta 'to be heard' to describe a process that explains perception from Kuroino and Watashi. Relation process shows intensity relation and meaning extension relation in a clause「山は ふわふわで暖かかった」Yama wa fuwafuwa de atatakakatta 'Its mound is soft and warm'. This clause has the attributive relational process, in which the participant is called carrier (yama 'mound') followed with attribute (fuwafuwa de atatakakatta 'soft and warm'). Thus, it can be understood that attribute shows condition, trait, and characteristics owned by a carrier. The verbal process shows notification or proclamation, such as「おもいきって声をかけた $ら 」$ Omoikitte koe wo kaketara 'I dare myself to greet him'. The verbal process has sayer (I) and verbiage (to greet him). Meanwhile, the behavioral process is not found in Kuroino text.

Based on transitivity analysis, the writer ideationally states imaginary adventure in detail, as experienced by two figures in the story, Kuroino and Watashi. Kuroino invites Watashi into a fictional world to visit the playground in which its entrance was in oshiire 'wardrobe'. In the park, they play happily, run everywhere, skate on a tree, and fall asleep on soft fur. The writer asks readers to participate in their adventure using questions and invitations. It seems that readers also participate in their experience.

Table 1 Amount of Process Type in Kuroino

\begin{tabular}{lcc}
\hline Processes & $\begin{array}{c}\text { Absolute } \\
\text { Values }\end{array}$ & Values in Percentages \\
\hline Material & 16 & 46 \\
Mental & 5 & 14 \\
Verbal & 3 & 9 \\
Relational & 4 & 11 \\
Behavioral & 0 & 0 \\
Existential & 7 & 20 \\
\hline Total & 35 & 100 \\
\hline
\end{tabular}

There are many relevant theories to analyze textual meaning. In this dimension, the clause is viewed as a meaning source used for organizing information and message (Halliday \& Matthiessen, 2014). The report considered the vital thing is prioritized by positioning in front of clause (theme), while the next part completes information (rheme). The theme is divided into three types, namely topical theme, interpersonal theme, and textual theme. The topical theme is the only thematic element required in the clause, implied in co(n)text or explicitly stated since it is mixed with some transitivity elements (Alamiri, 2018; Pasaribu, Sinambela, \& Manik, 2020). Halliday and Matthiessen (2014) have asserted that the sentence theme expands from the beginning to meet its transitivity function. The researcher's basis 
is to investigate thematization in periodicity (SFL) in text Kuroino. Besides, considering objectives of the research to examine patterns in theme development and information distribution, which is coherence in the text is by combining the theory of thematic progression stated by Danes in (Kizil \& Kushch, 2019) and Eggins in (Gunawan \& Aziza, 2017; Yunita, 2018), namely thematic progression with a linear theme, thematic progression with a continuous (constant) theme, and thematic progression with derived themes.

Information distribution on Kuroino text is textually stated through thematization with details of $27(77 \%)$ unmarked topical themes and $8(23 \%)$ marked topical themes. Realizing the unmarked topical theme means that Kuroino text has the main issue, as stated the most frequently through Kuroino and Watashi. The marked topical theme, circumstances from adverbs of time such as 'when going home' and 'today' is used to described adventure in detail. The interpersonal theme is not found in Kuroino's text. However, the textual theme is found in 20 clauses $(57 \%)$ from the whole text. The textual theme is realized with internal conjunction $(7 \%)$, external conjunction (23\%), and continuous marker (27\%). The use internal and external conjunctions, in a clause「塀の穴をくぐっていくと、花のにおい、 草のにおい」Hei no ana wo kugutte iku to, hana no nioi, kusa no nioi 'I crawled under wall hole in a house, after reaching the yard, I smelt flower and grasses' is used to combine experience gradually and in detail, as done by two figures. Besides, continuative markers, such as「ああ」 $a a$ 'wow', 「へえ」hee 'eh?',「あ れえ」aree 'eh' and so on are used to show emotion experienced by Watashi. The information presented in Kuroino's text tends to be organized through various occurrences at the clause level. Thus, it can identify a relation between theme and rheme in every clause in Kuroino text. For example, a wave from the center of the sea flows to the beach. This movement describes information flow in the text, which is continuous. Thus, in periodicity, text context is easy to be understood.

Theme development and information distribution in paragraph show that thematic progression with a linear theme is $27(80 \%)$, and thematic progression with a continuous (constant) theme is $7(20 \%)$. The data presented is a representation of the whole data in the Kuroino book. Data 1 belongs to thematic progression with a linear theme.

$$
\begin{aligned}
& \text { 「ろいのはやまをどんどんのぼってい } \\
& \text { く。やまはふわふわで、あたたかかった。 } \\
& \text { ふかふかかけにつつまれて、くろいのとい } \\
& \text { っしょにねむった。」 }
\end{aligned}
$$

Kuroino wa yama wo dondon nobotte iku. Yama wa fuwafuwa de, atatakakatta. Fukafuka no ke ni tsutsumarete, kuroino to isshoni nemutta

(Kuroino quickly climbed a mound. The mound was soft and warm. Then, I fell asleep with Kuroino covered by soft fur.)

The data shows that theme in the clause is developed from rheme in previous clauses, such as 'when Kuroino climbed a mound', followed with a theme which describes the mound 'Its mound was soft and warm', and it is told that 'they fell asleep on the mound'. This theme development dominates Kuroino's text following Denis's statement in Rezayi and Moghani (2018) about thematic progression with a linear theme, which is frequently found in fundamental reading material. Using this type will facilitate the reader in understanding the story plot.

Although thematic progression with a linear theme is the most dominant in text, another type is found in the text in the beginning and end, as shown in Data 2. Data 2 belong to thematic progression with a continuous (constant) theme, namely theme development based on the initial theme. At the beginning of the clause, Watashi and Kuroino meet for the first time, while the theme is developed from meetings with Kuroino in several opportunities. In this case, it is not explicitly stated in the next clauses since the Japanese language is known as a language with ellipsis of the word in a text when still discussing the same theme. Meanwhile, data in thematic progression with derived themes are not found in the text. The researcher assumes that topic development using this type will be difficult to understand by the reader older than three years.

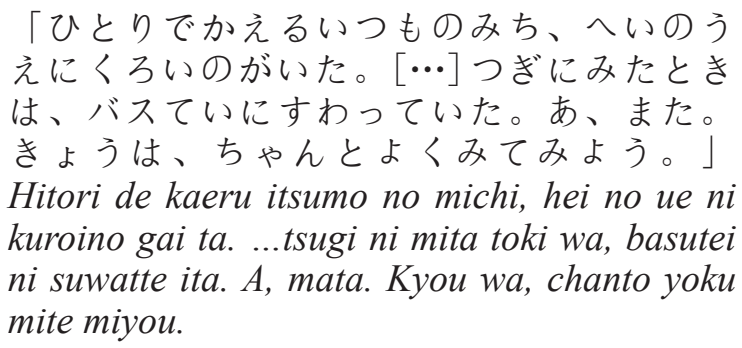

On the way which I usually passed, I saw Kuroino creature on the wall. The next day, I saw him sitting at the bus stop. Wow, he is there again. Today, I will try finding out about him.

After analyzing verbal text from the book Kuroino, the analysis focuses on three metafunctions of image (Kress \& van Leeuwen, 2020) related to three metafunctions of language (Halliday \& Matthiessen, 2014), namely representational, interactive, and compositional. The relation between SFL and VG in Table 2 as stated by Liu (2019). Thus, it can be said that the researcher treats the image as a language in this analysis phase provided that the picture is believed as a verbal language to realize its metafunction.

Table 2 Three Strands of Meta-functions in SFL and VG

\begin{tabular}{cc}
\hline SFL & VG \\
\hline Ideational & Representational \\
Interpersonal & Interactive \\
Textual & Compositional \\
\hline
\end{tabular}


Analysis of visual text data uses representational meaning, interactive meaning, and compositional meaning by Kress and van Leeuwen (2020). Representational meaning refers to the faithful reproduction of people's objective world, human activities, places, and even people's inner world. Kress and van Leeuwen (2020) have viewed that representational meaning can be obtained from two processes: narrative and conceptual processes. The vector is a criterion to identify whether it is the narrative process or a conceptual process. Besides, finding representational meaning reveals the relation between the represented participants (object in an image, a living creature, or inanimate object). The interaction process between defined participants is realized in a vector.

Participants in illustrated storybook Kuroino are Kuroino (the Black) and Watashi (I). Watashi is a girl aged 3-5 years. Watashi meets Kuroino for the first time when walking home. She sees a black creature sitting on the wall. The position of Watashi is on the lower left while staring at Kuroino. Meanwhile, the position of Kuroino is on the upper right while he looks around. Condition in the place shows a quiet street. The vector in Figure 1 is realized through stare from Watashi to Kuroino. Thus, Watashi is a reactor, while Kuroino becomes a phenomenon. Based on the vector, the relation between objects in the image belongs to the narrative process.

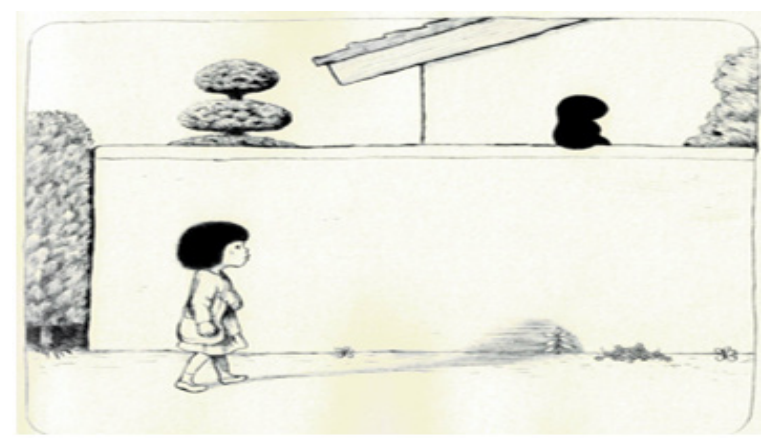

Figure 1 Narrative Process Image

Some visual data in a book Kuroino can be categorized into a narrative process that presents actions and characters' actions in their spatial arrangements. The spatial reference is often used to express feeling in Figure 2 with verbal data 「ねえ、

してるかな‥」Nee, shiteru kana... 'Hey, what are you doing?'

Besides expressing a feeling, the narrative process is shown from vector between Watashi and Kuroino in images 1, 2, 3, 4, 5, 6, 7, 8, 9, 10, 11, 12, $14,15,26,29$, and 31 , who try communicating to play together.

Visual data also have a conceptual process, namely static (no vector), and represented participants in terms of their more generalized and more or less stable and timeless essence in terms of class, structure, or meaning. It can be seen in Figure 3.

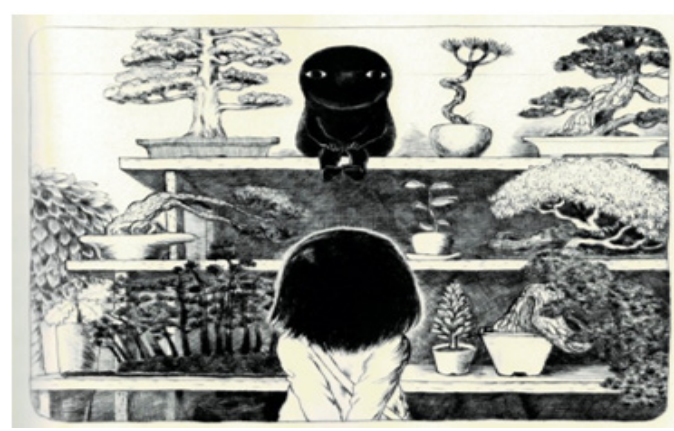

Figure 2 Action/Reaction Image

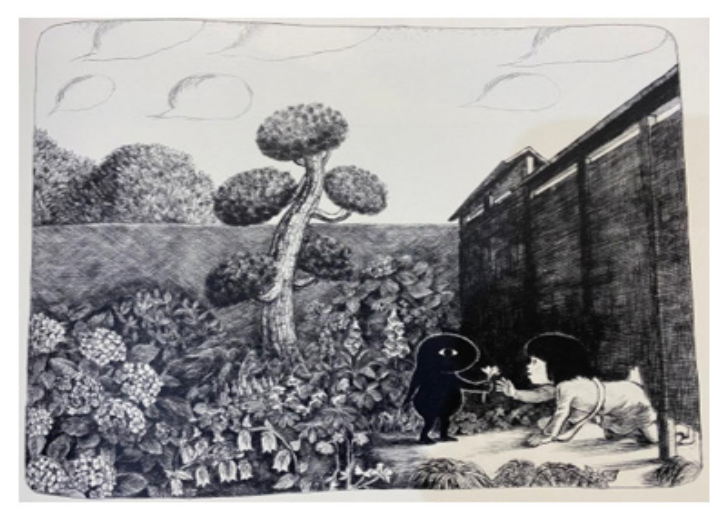

Figure 3 Conceptual Symbolic Image

Figure 3 shows Kuroino giving the flower to Watashi in a park where they do their exciting adventure. Although its color is monochrome (black and white), it clearly shows plants and flowers in the park, representing a beautiful place. Conceptual process is also shown in images 13,16,17, 18, 19, 20, $21,22,23,24,25,27,28,30$, and 32 . Visual data in the narrative process shows an amount that is almost the same as the conceptual process. It shows that the writer and illustrator in Kuroino invite the reader to enjoy Kuroino and Watashi's adventure by enjoying the environment where the experience takes place.

The illustrated book's interactive meaning is used to develop and maintain interaction between the message or image-maker and reader. According to Kress \& van Leeuwen (2020), some dimensions compile interactive meaning, namely contact, social distance, attitude, and modality. Contact in the visual text is established through the gaze from represented participants. In terms of gaze, represented participants in Kuroino do not directly communicate with the reader; all images belong to offer pictures. Kuroino and Watashi continuously stare at each other in all activities (e.g., walking on street, park, house) without involving the reader in any way besides receiving or refusing information made by the illustrator.

Social distance in images can determine the social relation between represented participants 
and the reader. Most of the pictures illustrated in Kuroino book belong to a far social distance, in which participants show their full body and readers can see the whole space. Thus, it can be said that the relation which dominates represented participants and reader is formal and impersonal. The illustrator does it as an effort to show readers (children) that these figures are from the imaginary world, not the real one. Besides, there are images in the category of far personal distance and close personal distance, in which participants are shown from shoulder to waist, so a relationship is established between represented participant and reader in the intimate and personal category. It shows that the story presented is from the imaginary world and the real world (Watashi is on the highway).

The next structure that establishes relation is the angle. There are two perspectives discussed by Kress \& van Leeuwen (2020), namely horizontal and vertical. Images in Kuroino are horizontally illustrated, so it can be said that illustrator and reader are involved with Watashi and Kuroino. Represented participants are shown in medium angle, in which relation between participant and reader is at the same level, so there is no dominance. At the same time, another dimension is a modality, how readers assess realism shown in images. Kuroino provides images in monochrome color, categorized into low modality in color differentiation aspect. However, in some contextualization aspects; representation, depth, illumination, and brightness can be categorized into high modality since the illustrated images are highly detailed in participant, background, a full representation of light and shade, and maximal degree of brightness.

Compositional meaning is achieved by the layout of the image, which consists of information value, salience, and framing (Kress \& van Leeuwen, 2020). The first principle is information value. It is the placement of several elements that give specific value, specific as in 'center/margin' and 'given/new'. In Kuroino, Watashi and Kuroino's participants are usually in the center of the image, as if they provide essential information from the whole picture. Thus, it can be said that these two participants are dominant in some pictures. Information structure given in the double-page book, Kuroino, shows the domination of verbal text on the left (given) and visual text on the right (new), as shown in Figure 4.

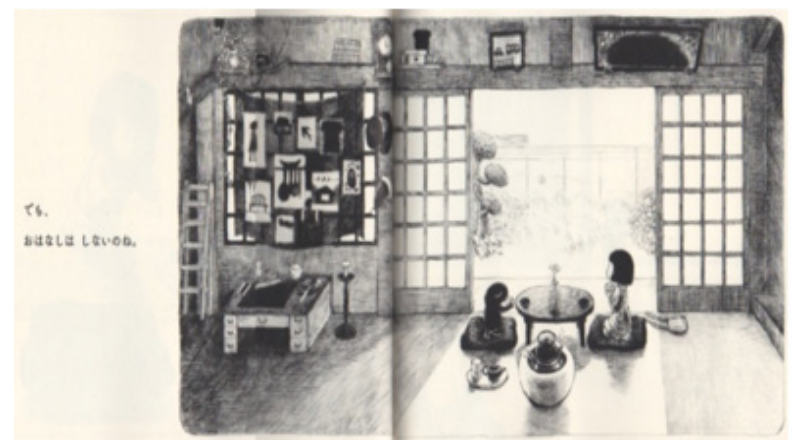

Figure 4 Compositional Meaning (Given/New Information)
Although it seems that visual and verbal texts are separated, they have relevance that completes each other. Represented participants, Kuroino and Watashi, are enjoying ocha (Japanese tea) with verbal text $\lceil て ゙$ も、お話はしないね」Demo, ohanashi wa shinaine 'But, Kuroino is not saying any single word at all'. It shows that they are enjoying a drink while looking at the park without saying any word.

Salience is the second principle of layout discussed by Kress \& van Leeuwen (2020). It refers to the degree to which an element of composition or design draws attention to itself. It includes all participant elements made to attract readers, such as size, the sharpness of focus, tonal contrasts, color contrasts, placement in the visual field, and perspective. The researcher uses not all aspects in salience to analyze since visual text data on Kuroino is monochrome. As shown in Figure 2, the size of Kuroino and Watashi is almost like a human being in general based on proportion with the environmental condition (image background). Although the researcher cannot use color as an aspect to be analyzed, the tonal contrast of the image is detailed, as shown in Figure 3. It shows how the illustrator describes a park full of beautiful flowers as if they have many colors. When Kuroino and Watashi focus on some stories, they are described as the center's position, more oversized shape, and more plain background.

The third principle of composition is discussed by Kress \& van Leeuwen (2020). There is no framing in Kuroino, which indicates involvement and absence of social distance between represented participants and readers (children). The lack of structure creates intersemiotic compositional cooperation between visual and verbal, which relates to each other and provides a taste of unity.

After analyzing meaning based on verbal and visual texts, the researcher interprets the meaning, whether or not it completes each other. Thus, it can be understood the meaning to be conveyed by the writer and illustrator, whether or not it synergizes and has meaning. The researcher describes a relation in verbal and visual texts based on an opinion stated by Liu (2019), in which every aspect of meaning in the three metafunctions of language will be compared with that in the three metafunctions of image.

Analysis of ideational meaning in the verbal text shows the domination of Mood indicativedeclarative, a clause which states information about the adventure of the represented participant. It is supported by representational meaning in the visual text, which is almost the same between narrative and conceptual processes. It can be interpreted that the writer and illustrator in Kuroino invite the reader to enjoy the adventure by Kuroino and Watashi by enjoying the environment where the incident occurred. Besides, interpersonal meaning shows the domination of material processes $(46 \%)$ and existential processes (20\%), which tend to be found in children's stories. Children's narrative explains what is done by the character and represents what is thought and felt. 
Besides, interactive meaning in the visual text uses analysis elements, namely contact, social distance, attitude, and modality. Data analysis shows the represented participants between imaginary and real worlds. As demonstrated by formal and impersonal domination in the social space; what is done by the designated participant without approval or rejection from readers (viewed from offer image); the relation between participant and reader at the same level (horizontally shown from the perspective and medium angle); in realism, illustration seems real with beautiful details, though illustrated using black and white color.

Textual meaning in the verbal text uses thematic progression theory. It shows linear theme domination, though thematic progression with a continuous (constant) theme on story plot is also found. It exhibits a strong relation in a clause that delivers an information message with two main characters in the story. The story is told in a structured and thematic way with a simple pattern easily understood by the reader. It is supported by compositional meaning in the visual text, which is evident with a visual component in detailed black and white images describing two characters, a girl and a black creature, in an imaginary adventure. It is related to environmental aspects of nature, such as highway, park, house, tree, flower, and others as additional aspects of the two characters' support story.

\section{CONCLUSIONS}

The research conclusion shows that in verbal text, the meaning of a clause in a book entitled Kuroino, which is analyzed by using the three metafunctions of language, shows the meaning relevance. The interpersonal meaning states information exchange (indicative-declarative) between writer and reader about friendship and adventure between Kuroino and Watashi. It is supported by ideational meaning (transitivity analysis) that the writer conveys an imaginary adventure in detail, which is experienced by these two characters. Besides, in the textual meaning, which shows the domination of thematic progression with a linear theme, the writer develops theme and distribution of information (e.g., following one after another) in text, so the story about friendship and adventure between these two characters is easily understood. Meanwhile, meaning in the visual text, which is analyzed using the three metafunctions of images, shows the meaning of relevance. Representational meaning shows the same amount between the narrative process and conceptual process, provided that the illustrator in a book entitled Kuroino invites the readers to participate in adventure while enjoying the surrounding environment or condition. The illustrator expects to develop and maintain the relationship with readers, as shown in interactive meaning. Besides, the structure of information provided in a double-page book entitled Kuroino shows the domination of a 'given-new' structure.
Thus, although it seems that verbal and visual texts are separated, they have a relevance that completes each other. Based on the explanation, the meaning in verbal and visual texts of a storybook entitled Kuroino creates a relation that synergizes each other and has meaning. The writer and the illustrator create a message which completes each other.

It can be said that Kuroino is one of the picture books made for children using simple vocabulary and a simple plot to tell a story. It is supported with a visual presentation to keep the storyline, so children can easily understand the story without double meaning. Besides, verbal and visual texts avoid monotonous aspects from the story. The implication of the research is expected to enrich the reference related to the implementation of SFL and VG in Japanese children's picture books. It can also give a contribution to recommending quality children's literature from the perspective of linguistics. The limitation of the research is indicated by using one data source only, a picture book for children older than three years, the suggestion for the next research is the use of several picture books for children of several ages. Besides, it can be focused on a storybook with a specific theme (e.g., fable or others) in the Japanese language.

\section{REFERENCES}

Alamiri, Z. (2018). SFL-based analysis of thematic structure of the Qur'ān (19:41-50): Some reflections. The Buckingham Journal of Language and Linguistics, 11, 21-52. https://doi.org/10.5750/bj1l.v11i0.1560.

Attiyat, N. M. A. (2019). The impact of pleasure reading on enhancing writing achievement and reading comprehension. Arab World English Journal, 10(1), 155-165. https://doi.org/10.24093/awej/ vol10no1.14.

Belcher, C. (2018). Culture through children's picture books: A new kind of reading or a new kind of child? IAFOR Journal of Cultural Studies, 3(2), 29-41. https://doi.org/10.22492/ijcs.3.2.03.

Cao, Y., \& Yin, J. (2016). A new perspective to study children's literature: From the systemic functional grammar perspective. Linguistics and Literature Studies, 4(6), 433-440. https://doi.org/10.13189/ 1ls.2016.040607.

Doi, Y., Hiromatsu, Y., Nogami, A., Sakuma, Y., \& Shiozaki, J. (2020). Japanese children's books 2020: JBBY's recommendations for young readers throughout the world. (Y. Sakuma, Ed.). Tokyo: Poplar Publishing Co., Ltd.

Gunawan, W., \& Aziza, F. (2017). Theme and thematic progression of undergraduate thesis: Investigating meaning making in academic writing. Indonesian Journal of Applied Linguistics, 7(2), 413-424. https://doi.org/10.17509/ijal.v7i2.8350.

Halliday, M. A. K., \& Matthiessen, C. M. I. M. (2014). Halliday's introduction to functional grammar: Fourth edition. London and New York: Routledge. https://doi.org/10.4324/9780203431269. 
Hayakawa, C. (2015). The system of relationships between words and pictures in picturebooks. Japanese Journal of Systemic Functional Linguistics, 8, 115140.

Hermawan, B., \& Sukyadi, D. (2017). Ideational and interpersonal meanings of children narratives in Indonesian picturebooks. Indonesian Journal of Applied Linguistics, 7(2), 404-412. https://doi. org/10.17509/ijal.v7i2.8139.

Inako, A. (2017). But the meaning disappears when translated into English: Glossing choices in a discourse semantic exploration of Japanese. In P. Chappell \& J. S. Knox (Eds.), Transforming Contexts: Papers from The $44^{\text {th }}$ International Systemic Functional Congress (pp. 5-11). Wollongong: The Organising Committee of the $44^{\text {th }}$ International Systemic Functional Congress.

Indrowaty, S. A., Djatmika, D., Purnanto, D., \& Hariri, T. (2018). Analyzing the structure and the texture of Japanese advertisement (A systemic functional linguistics approach). In $4^{\text {th }}$ PRASASTI International Conference on Recent Linguistics Research (Vol. 166, pp. 293-301). Hong Kong: Atlantis Press. https://doi.org/10.2991/prasasti-18.2018.56.

Irhandayaningsih, A. (2019). Menanamkan budaya membaca pada anak usia dini. Anuva, 3(2), 109-118. https://doi.org/10.14710/anuva.3.2.109-118.

Kimura, H. (2019). Data-based discussion on education and children in Japan 4: Issues regarding Japanese children's reading--In association with the effects of reading. Retrieved September 9, 2020, from https://www.childresearch.net/projects/data Japan/2019_02.html.

Kizil, M., \& Kushch, E. (2019). Thematic progression and its types in English literary and legislative texts. Advanced Education, 2019(12), 181-187. https://doi. org/10.20535/2410-8286.142658.

Koutsikou, M., \& Christidou, V. (2019). The interplay between interpersonal and compositional meanings in multimodal texts about animals for young children. Punctum, 5(1), 114-137. https://doi.org/10.18680/ hss.2018.0008.

Kress, G., \& van Leeuwen, T. (2020). Reading images (3 ${ }^{\text {rd }}$ Ed.). London and New York: Routledge. Retrieved from https://www.routledge.com/Reading-ImagesThe-Grammar-of-Visual-Design/Kress-Leeuwen/p/ book/9780415672573.

Liu, S. (2019). A multimodal discourse analysis of the interactive meaning in public service advertisement. Journal of Advances in Linguistics, 10, 1523-1534. https://doi.org/10.24297/jal.v10i0.8196.

Maharsi, I., Ghali, M. I., \& Salma, M. U. (2019). High school students' reading habit and perception on reading for pleasure. International Journal of Indonesian Education and Teaching, 3(2), 204-214. https://doi. org/10.24071/ijiet.2019.030108.

Maximo, M. (2019). Storybook reading strategies to enhance English skills with preschool children in Honduras. Paradigma Revista de Investigacion Educativa, 26(41), 46-68. http://dx.doi.org/10.5377/ paradigma.v26i41.7975.

Miles, M. B., Huberman, A. M., \& Saldafia, J. (2020).
Qualitative data analysis: A methods sourcebook (Fourth). Los Angeles, London, New Delhi, Singapore, Washington DC, Melbourne: Sage Publications, Inc.

Moya Guijarro, J., \& Pinar Sanz, M. J. (2008). Compositional, interpersonal and representational meanings in a children's narrrative: A multimodal discourse analysis. Journal of Pragmatics, 40(9), 1601-1619. https://doi.org/10.1016/j.pragma.2008.04.019.

Murray, N. (2020). A multimodal analysis using an exemplar from Japanese television advertising. Athens Journal of Mass Media and Communications, 6(3), 161-176. https://doi.org/10.30958/ajmmc.6-3-2.

Ngongo, M., Dethan, M., \& Hyna, H. B. (2018). Metafunction meaning realization in lexicogrammar of sermon texts on language and cultural month, Kupang town: A systemic functional linguistic approach. In International Conference on Language Phenomena in Multimodal Communication (Vol. 228, pp. 214-225). Netherland: Atlantis Press. https://doi.org/10.2991/klua-18.2018.31.

Pasaribu, A. N., Sinambela, E., \& Manik, S. (2020). The contributions of systemic functional linguistics to literary text analysis. International Journal of Linguistics, Literature and Translation (IJLLT), 3(9), 81-86. https://doi.org/10.32996/ijllt.

Qiu, Q. (2019). A multimodal analysis of the interplay between visual and verbal semiotics in creating messages in Chinese picture books. CS Canada Studies in Literature and Language, 19(3), 44-50. https://doi.org/10.3968/11444.

Raeisi, M., Dastjerdi, H. V., \& Raeisi, M. (2019). Lexicogrammatical analysis of native and non-native abstracts based on Halliday's SFL model. Theory and Practice in Language Studies, 9(11), 1388. https://doi.org/10.17507/tpls.0911.03.

Ratminingsih, N. M., \& Budasi, I. G. (2018). Local culturebased picture storybooks for teaching English for young learners. In A. G. Abdullah, J. Foley, I. G. N. A. Suryaputra, \& A. Hellman (Eds.), SHS Web of Conferences (Vol. 42, p. 00016). Bali: EDP Sciences. https://doi.org/10.1051/shsconf/20184200016.

Rezayi, S. T., \& Moghani, H. (2018). The status of theme types and thematic progression patterns in English written biography texts: A systemic functional approach. Linguistics Journal, 12(1), 45-69.

Sembiante, S. F., Baxley, T. P., \& Cavallaro, C. J. (2018). What's in a name? A critical literacy and functional linguistic analysis of immigrant acculturation in contemporary picture books. Diaspora, Indigenous, and Minority Education, 12(1), 28-41. https://doi.or $\mathrm{g} / 10.1080 / 15595692.2017 .1350640$.

Steele, D., Zhang, R., \& Song, S. (2018). The impact of manga on Japanese students' reading habits. In $A C M$ International Conference Proceeding Series (pp. 206-211). Bali, Indonesia: ACM Digital Library. https://doi.org/10.1145/3291078.3291112.

Sudaryanto. (2015). Metode dan aneka teknik analisis bahasa. Yogyakarta: Sanata Dharma University Press.

Tanaka, K. (2019). Kuroi no. Tokyo: Kaiseisha. 
Tse, S. K., Zhu, Y., Hui, S. Y., \& Ng, H. W. (2017). The effects of home reading activities during preschool and grade 4 on the effects of home reading activities during preschool and grade 4 on children's reading performance in Chinese and English in Hong Kong. Australian Journal of Education, 61(1), 5-23. https:// doi.org/10.1177\%2F0004944116689093.

Wee, S.-J., Kura, K., \& Kim, J. (2018). Unpacking Japanese culture in children's picture books: Culturally authentic representation and historical events/ political issues. Reading Horizons: A Journal of Literacy and Language Arts, 57(2), 35-55.

Yunita, S. (2018). Theme and thematic progression in students' recount texts. Indonesian Journal of Applied Linguistics, 7(3), 524-530. https://doi. org/10.17509/ijal.v7i3.9797.

Zohrabi, M., Dobakhti, L., \& Mohammadpour, E. (2019). Interpersonal meanings in children's storybooks. Iranian Journal of Language Teaching Research, 7(2), 39-64. https://dx.doi.org/10.30466/ ijltr.2019.120697. 